\title{
Tolerance in the Postindustrial City
}

\section{Assessing the Ethnocentrism of Less-Educated \\ Natives in 22 Dutch Cities}

Jeroen van der Waal and Dick Houtman

Address of correspondence

Jeroen van der Waal

Department of Sociology

Faculty of Social Sciences

Erasmus University

P.O. Box 1738

3000 DR Rotterdam

The Netherlands

\author{
Telephone \\ $+31-10-4088668 / 2085$ \\ Fax \\ $+31-10-4089098$ \\ Email \\ vanderwaal@fsw.eur.nl
}




\section{Biographical notes}

Jeroen van der Waal (1974) is assistant professor at the department of sociology, Erasmus University Rotterdam, the Netherlands. His research interests are twofold. On the one hand he studies the impact of economic globalization and post-industrialization on social inequality and ethnic relations in cities in the advanced economies, on which he published in Urban Studies (2009, 2011). On the other hand, he is engaged in research on the impact of cultural change on value orientations and voting behavior in the west, on which he published in journals such as British Journal of Criminology (2008), International Political Science Review (2007), Journal for the Scientific Study of Religion (2009), Journal for European Social Policy (2010), and Politics \& Society (2007).

Dick Houtman (1963) is professor of cultural sociology at the Center for Rotterdam Cultural Sociology (CROCUS) at Erasmus University Rotterdam, the Netherlands. Most of his research addresses cultural change in contemporary western societies, with a focus on its political and religious ramifications. His latest books are Farewell to the Leftist Working Class (with Peter Achterberg and Anton Derks 2008, New York: Transaction) and Religions of Modernity (edited with Stef Aupers 2010, Leiden: Brill). In recent years, he has also published in European Journal of Political Research, Social Forces, Politics \& Society, Public Opinion Quarterly, British Journal of Criminology, Journal of European Social Policy, American Behavioral Scientist, Journal of Contemporary Religion, and Journal for the Scientific Study of Religion. 


\title{
Tolerance in the Postindustrial City
}

\section{Assessing the Ethnocentrism of Less-Educated Natives in 22 Dutch Cities}

\begin{abstract}
This article studies whether and why less-educated natives are less ethnocentric in postindustrial Dutch cities than in industrial ones, as suggested by several theories in urban studies. A multilevel analysis of survey data collected among the native working populations (source: Cultural Change in the Netherlands Surveys 2004 and 2006) of 22 Dutch metropolitan agglomerations (sources: Statistics Netherlands Statline and Atlas of Municipalities) confirms that those concerned are indeed less ethnocentric in the most postindustrial cities. This pattern proves not to stem from the better opportunities at the bottom end of the labor market in these cities, as the ethnic competition theory suggests, but from the more tolerant cultural climate in these cities, as emphasized by Richard Florida in his work on creative cities.
\end{abstract}

\section{Keywords}

Richard Florida, Creative city, Bohemian index, Urban culture, Cultural tolerance 
It has long been known that cultural and political intolerance in general, and towards ethnic minorities in particular, can in the west mainly be found among the less educated (Emzler and Frazer 1999). Recent theorizing about 'new political culture cities' (Clark 1996; Sharp 2007; Sharp and Joslyn 2008), 'unconventional cities' (Rosdil 1991; Sharp 2002) and 'post-traditional cities' (Sharp 2007) suggests, however, that this may be less so in postindustrial cities than in industrial ones. This article therefore studies whether less-educated natives are indeed less ethnocentric in postindustrial cities than in industrial ones and, if so, how exactly this can be explained. It so happens that there are two markedly different theories that predict such a difference between industrial and postindustrial cities - or, more formally stated, between less and more postindustrial cities (for the sake of readability, we will often use the former shorthand formulation in what follows).

The first theory is informed by central insights from the work of Richard Florida $(2002,2003,2004,2005)$ and maintains that an urban climate of cultural tolerance is responsible for such a difference. The second theory, which combines insights from the work of Saskia Sassen $(2000,2001,2006)$ with the so-called 'ethnic competition theory', claims that it results from better economic opportunities at the bottom end of the labor market in postindustrial cities. In what follows, we first elaborate these two theories, starting with the latter, and then test the relevant hypotheses by means of a multilevel analysis of ethnocentrism among the native working populations of 22 Dutch metropolitan agglomerations that differ in the extent to which they are postindustrial.

\section{The Economic and Cultural Climate of the Postindustrial City}


$\underline{\text { Postindustrialism, labor-market opportunities and ethnocentrism }}$

According to Sassen, the transition to a postindustrial economy has vast consequences for the demand for less-skilled labor $(2000,2001,2006)$. For two reasons, this demand is supposed to be higher in cities with a large share of 'advanced producer services' (the hallmark of postindustrial urban development) than in industrial cities, i.e., cities where these services comprise only a marginal share of the urban labor force. Firstly, Sassen (2006, 197, cf. 2000, 142) emphasizes that "almost half the jobs in the producer services are lower-income jobs, and the other half are in the two highest earning classes". The latter half consists of the higher-educated professionals such as financial specialists, accountants and consultants; the former half of the less-educated workers who accommodate these professionals: cleaners, servants and clerks (Sassen 2000, 14, cf. 2006, 197). Sassen moreover maintains that the consumption patterns of well-educated professionals employed in the advanced producer services increase the demand for lowereducated labor even further, because their lifestyles create employment opportunities for "an army of low-wage workers (...) including residential building attendants, dogwalkers, housekeepers for the two-career family, workers in the gourmet restaurants and food shops, French hand laundries, and so on" (Sassen-Koob 1985, 262).

And indeed, several studies show that urban economies with a strong and growing presence of advanced producer services increase the prosperity of their citizens irrespective of ethnicity and education level (Drennan et al. 2002), and create jobs for the highly as well as lowly educated. Cities with a more industrial character, on the other hand, have witnessed a decline of the prosperity of their citizens in recent decades - 
especially of the less-educated stratum (Drennan et al. 2002) - and have to contend with high unemployment levels at the bottom end of the labor market. This has been documented for cities in the United States (Elliott 1999, 2004; Kasarda 1985; Kasarda and Friedrichs 1985) the former Federal Republic of Germany (Kasarda 1985; Kasarda and Friedrichs 1985), and the Netherlands (Van der Waal 2010; Van der Waal and Burgers 2009a, 2009b, 2011).

Recent studies show that the already high unemployment levels among the less educated in Dutch industrial cities have further been aggravated by the influx of immigrants. Contrary to postindustrial ones, these cities have hence not been able to absorb this influx, so that competition between immigrants and less-educated natives is particularly fierce in industrial cities (Van der Waal 2009, 2010a, 2010b, 2011).[1] According to several scholars in urban studies such ethnic competition spurs ethnocentrism among less-educated native urbanites (e.g., Fainstein, Gordon, and Harloe 1992; King 1990; Wacquant 2008). This so-called 'ethnic competition theory' is quite prominent outside urban studies, too, if only because it is based on Max Weber's widely used classical notion of 'social closure' ([1922] 2006; cf. Roscigno, Garcia, and BobbittZeher 2007), according to which "competition for resources leads to attempts at exclusion of one group by another" (Olzak 1992, 163; cf. Blalock 1956, 1967).

According to this ethnic competition theory, then, it can in the first place be expected that less-educated natives are more ethnocentric than higher-educated ones because of their weak economic position (hypothesis 1a). Moving from the individual level of analysis to the city level, this theory suggests that less-educated natives in the 
most postindustrial cities will be less ethnocentric due to these cities' more favorable economic opportunity structures (hypothesis 2a).

\section{Postindustrialism, cultural climate and ethnocentrism}

The transition to a postindustrial economy is not only accompanied by the labor market changes addressed above, however, but also by changes in the cultural climate of cities: postindustrial cities are held to have a more tolerant cultural climate that positively affects the cultural tolerance of their citizens (Clark 1996; Clark and Rempel 1997; Sharp 1996, 2002, 2007; Sharp and Joslyn, 2008). This argument figures particularly in the influential work of Richard Florida on the creative class and creative cities.

According to Florida, besides technological innovation and talent, a tolerant cultural climate is an important pre-condition for a thriving urban economy because such a climate attracts members of the creative class $(2002,2003,2004,2005)$. This class is held responsible for technological innovation and hence new forms of industriousness in urban economies. The question whether urban economic growth is indeed driven by this mechanism is widely debated (cf. inter alia Asheim and Hansen 2009; Hoyman and Faricy 2009; Markusen and Schrock 2006), but not directly relevant here. What is important is that the most postindustrial cities in both the United States (Florida 2004, 2005) and the Netherlands (Van der Waal 2010a, 2010b) seem indeed to have the most tolerant cultural climate, as measured by means of Florida's 'bohemian index'.

This index is based on the share of the urban population that is involved in the production of culture and the arts, because those concerned are assumed to be attracted by a tolerant urban climate (cities like San Francisco, Amsterdam, and Berlin being 
examples par excellence). As such, according to Florida the bohemian index indicates 'an underlying openness to diversity' (Florida 2002, 64, 2004, 260, 2005, 113-28) at the city level, that is neither simply the result of the level of cultural tolerance of urbanites generally, nor of these bohemians in particular (Deleon and Naff 2004; Florida 2002, 2003, 2004, 2005). The bohemian index thus aims to measure a phenomenon sui generis, i.e., a climate of cultural tolerance that increases levels of tolerance of individual urbanites in a similar way as, for instance, the manner in which the cultural climate in the south in the United States decreases it: irrespective of their level of education, southerners are more ethnocentric than in Americans in northern states (e.g., Kuklinski, Cobb, and Gilens 1997; Oliver and Mendelberg 2000; Weakliem and Biggert 1999).

What Florida's theory has in common with the ethnic competition theory is the assumption that less-educated natives are least ethnocentric in the most postindustrial cities. It does however propose a markedly different explanation for such a pattern. While according to the ethnic competition theory it is the result of better labor market opportunities at the bottom end of the urban labor market, Florida attributes it to a tolerant urban cultural climate that is more sympathetic towards cultural diversity. This assumption that culture instead of economic conditions is decisive for explaining ethnocentrism is consistent with four sets of research findings.

The first set of findings shows that less-educated natives particularly resist immigrants who are ethnically and/or culturally different (Dustmann and Preston 2007; Fuchs, Gerhards, and Roller 1993; Sniderman, Hagendoorn, and Prior 2004; Sniderman and Hagendoorn 2007), and that they consider immigrants a cultural rather than an economic threat (Kluegel and Smith 1983; O'Rourke and Sinnott 2006; Sniderman, 
Hagendoorn, and Prior 2004; Sniderman and Hagendoorn 2007). The second set of findings suggests that the ethnocentrism of less-educated natives is rooted in their cultural background rather than the fierce competition over scarce resources they have to face up to: ethnocentrism can not, or hardly, be explained from their weak labor market position, measured unambiguously in terms of income or unemployment, but education is decisive in and of itself (Achterberg and Houtman 2006; Elchardus and Siongers 2009; Houtman, 2001, 2003; Houtman, Achterberg and Derks 2008; Van der Waal 2010a, 2010b; Van der Waal and Burgers 2011; Van der Waal et al., 2010).

These two sets of research findings suggest that in western liberal democracies and in western liberal democracies only (Weil 1985) - education affects ethnocentrism as a vessel for what Bourdieu $(1984,1986)$ has called (institutionalized) 'cultural capital' rather than 'economic capital'. This seems to be because such cultural capital entails a reflexive, 'de-naturalized' and 'de-reified' (Gabennesch 1972) understanding of culture as socially and humanly constructed and as such ultimately contingent and radically different from the givens of nature (Bauman 1987). In such an understanding of culture, one's 'own' culture is not considered the norm, but understood as just one particular way of giving meaning to the world and engendering social order. Those with ample cultural capital therefore neither consider their 'own' culture unproblematic, nor do they conceive of 'other' cultures as 'deviant' or 'problematic', but simply observe different, changing and ultimately arbitrary value patterns and life styles. Those with low levels of cultural capital, on the other hand, conceive 'social reality as encompassing a superordinate normative dimension, an external locus where events are determined, where moral authority resides, and to which men must adapt themselves' (Gabennesch 1972, 862-3). 
As a result, they consider other lifestyles and value patterns as violations of the social and cultural order, and therefore resist the cultural diversity that immigrants and ethnic minorities bring in their wake.[2]

That education does indeed affect ethnocentrism as a vessel for institutionalized cultural capital rather than as an indicator for economic capital is furthermore indicated by a third set of research findings about the relationship between an ability to actually understand and appreciate arts and culture (Bourdieu (1986) uses the term 'embodied cultural capital') on the one hand and ethnocentrism on the other. Unlike economic corollaries of education such as income and unemployment, this cultural corollary of education is strongly related to ethnocentrism: those with a low amount of embodied cultural capital experience cultural diversity as more of a threat than those with ample embodied cultural capital, even apart from the fact that education is strongly and positively related to both (Elchardus and Siongers, 2009; Manevska et al., 2010; Van der Waal et al., 2010). This suggests that education, too, operates as an indicator for cultural capital rather than one's economic position when it comes to understanding its relation with ethnocentrism.

According to this theory, then, the relationship between education and ethnocentrism needs to be understood from the circumstance that those with little cultural capital understand other lifestyles and value patterns as illegitimate deviations from a 'non-negotiable' social order which demands conformity. In the eyes of those with little cultural capital, then, this social order is seen as being disrupted when 'deviant' lifestyles and value patterns proliferate in the wake of mass immigration, arousing feelings of cultural insecurity and anomie.[3] Desires of restoring a stable, predictable and 
meaningful social order then inform resistance to immigrant and ethnic minority groups who are seen as disrupting it.

This is indeed what the fourth and last relevant set of research findings points out, suggesting once again that the high levels of ethnocentrism among the less educated result from their cultural capital rather than their economic position. It has after all not only been found time and again that cultural insecurity is especially strong among the less educated, but also that it can hardly be attributed to their weak economic position apart from (allegedly) education (Elchardus and Smits 2002; De Groof and Elchardus 2009; Manevska et al. 2010; McDill 1961; Mulford 1968; Radkiewicz 2007). Furthermore, this cultural insecurity of the lower educated has often been shown to be strongly related to cultural intolerance generally (Achterberg and Houtman 2009; Blank 2003; Derks 2006; Elchardus and Smits 2002) and towards ethnic minorities in particular (Elchardus and Siongers 2009; Fuchs 2003; Lutterman and Middleton 1970; Manevska et al. 2010; McDill 1961; Mulford 1968; Radkiewicz 2007; Roberts and Rokeach 1956; Srole 1956). Whereas the ethnic competition theory attributes the high level of ethnocentrism of less-educated natives to their weak economic position, then, this alternative theory suggests that it rather is their small amount of cultural capital and the cultural insecurity that comes with it that is decisive (hypothesis 1b). Moving from the individual level of analysis to the city level, the ethnic competition theory predicts that less-educated natives will be less ethnocentric in postindustrial cities because of the latter's better economic opportunity structures, whereas this alternative theory rather holds that it is the tolerant cultural atmosphere of these cities, as measured by Florida's bohemian index (Van der Waal 2010a, 2010b), that is decisive (hypothesis 2b). 
Data and Operationalization

Data.

We will test our hypotheses with a data-set that combines city-level data for the 22 Dutch metropolitan agglomerations as delineated by Statistics Netherlands (Centraal Bureau voor de Statistiek, CBS) (see appendix) with individual-level survey data on their populations. The latter data were retrieved from the 2004 and 2006 waves of the 'Cultural Change in the Netherlands' survey (Culturele Veranderingen in Nederland), which is a bi-annual survey conducted by 'The Netherlands Institute for Social Research' (Sociaal Cultureel Planbureau, $S C P$ ) with a sample that is representative for the Dutch population at large.[4] Combining two waves was necessary to attain a sufficiently large number of native respondents $(\mathrm{N}=765)$ from the working population (18 to 65 years old) living in the 22 metropolitan agglomerations. These individual-level data have been combined with city-level data retrieved from the 2004 and 2008 wave of the 'Atlas for Municipalities' (Atlas voor Gemeenten 2004 and 2008) and Statistics Netherlands (Centraal Bureau voor de Statistiek, CBS).[5]

Operationalization individual-level variables [6].

Ethnocentrism is a scale constructed out of four items that express opinions about immigrants and immigration. Three of these items remain very close to the theoretical rationale of the ethnic competition theory in that they revolve around whether 'a foreigner' or 'a native Dutchman' is considered most entitled to scarce economic 
resources, thus addressing precisely the type of distributive conflict assumed by this theory. The fourth item asks the respondent's opinion on the number of people without the Dutch nationality in the Netherlands (see table 1).

\section{[Table 1 about here]}

Economic position is measured with two indicators: income (i.e., net family income of the respondent) and unemployed, which codes the employed and student respondents as 1 , and unemployed respondents as 2 .

Education is a more ambiguous indicator for one's economic position than either income or unemployed, because it simultaneously taps into one's (institutionalized) cultural capital. It is measured as the minimum number of years of schooling needed to attain the highest level of education achieved by the respondent. To facilitate the interpretation of the results of the analyses below, we have dichotomized this variable into two categories of roughly equal size. Respondents with less than 16 years of schooling have been coded as $1(\mathrm{~N}=384)$ and those with at least 16 years as $2(\mathrm{~N}=381)$. Cultural participation is used next to education, because contrary to education it does not tap into one's economic position and hence constitutes a less ambiguous and more explicit measure of (embodied) cultural capital (cf. Houtman 2003; Manevska et al. 2010; Van der Waal 2010b). It is measured with a widely used scale consisting of four questions about highbrow cultural consumption (see table 2) (e.g., DiMaggio 1982; DiMaggio and Mohr 1985; Dumais 2002; Eitle and Eitle 2002; Katsillis and Rubinson 1990). 


\section{[Table 2 about here]}

Cultural insecurity is measured with four items that closely resemble those of the widely used scale of Srole (1956) on this matter (table 3).

\section{[Table 3 about here]}

\section{Operationalization city-level variables.}

Postindustrialism is measured as the share of the working population that is employed in the advanced producer services minus the share of the working population employed in manufacturing according to the Dutch SBI 93 classification (Standaard Bedrijfsindeling 1993), which corresponds to the 'ISIC Rev. 3.1' (International Standard Industrial Classification of All Economic Activities) of the United Nations. Advanced producer services is the share of the working population employed in firms classified in classes $\mathbf{J}$ (finance) or K (real estate and producer services). According to Sassen (2000, 2001, 2006), particularly these economic activities account for the increased demand for lesseducated workers in contemporary urban economies, an assumption that has been corroborated for Dutch cities several times (Van der Waal 2010a, 2010b; Van der Waal and Burgers 2009a, 2009b, 2011). Manufacturing measures the share of the working population employed in firms classified in class D (manufacturing).

Economic opportunity structure is measured as the share of less-educated urbanites registered at the unemployment agency as looking for a job of at least 12 hours a week, the latter being the official criterion for being unemployed in the Netherlands. Because the unemployed are not entitled to unemployment benefits without such 
registration, this provides us with a valid measure of the share of the less-educated population that is actually looking for a job to provide themselves with means for subsistence. This variable ranges from 4.4 through 8 percent and has been recoded in such a way that high scores indicate low unemployment among less-educated urbanites. Put differently, higher scores indicate less competition over scarce job entries at the bottom of the labor market and hence more labor market opportunities for those concerned. As Sassen assumes, this measure of economic opportunity structure does indeed correlate strongly with postindustrialism (Pearson's $r=0.442, p<0.05, \mathrm{~N}=22$ ): the economic opportunity structure for the less educated is most favorable in the most postindustrial cities.

The bohemian index has been introduced by Florida $(2002,2004)$ as a measurement of the level of tolerance of the urban cultural climate by means of the share of bohemians in the urban population. More specifically, the index measures the share of the urban population that is involved in the production of culture and the arts (for instance: writers, designers, architects, composers, painters, sculptors, photographers and actors). The assumption that underlies this measurement is that a culturally tolerant atmosphere attracts these bohemians, so that the larger their relative number, the more tolerant the urban cultural climate will be. Index scores range from 0.07 through 2 percent and like economic opportunity structure it is substantially correlated with postindustrialism (Pearson's $r=0.670, p<0.01, N=22$ ): the most postindustrial cities score highest on the bohemian index and hence allegedly have the most tolerant cultural climate. 


\section{$\underline{\text { Operationalization control variables }}$}

Next to the variables needed for testing the hypotheses there is a need to control for some demographic characteristics of the urban population, because these differ between cities and are related to ethnocentrism, too. These controls are gender (female respondents have been coded as 1 , male respondents as 2 ) and age (in number of years). The analyses that follow will also control for the fact that the data-set combines two surveys. This will be done by modeling year, which codes respondents from the 2004 survey as 2004 , and respondents from the 2006 survey as 2006.

Next to these individual-level control variables the analyses will use one city-level control variable: immigrant share. It measures the share of non-western immigrants in the urban population and varies from 5.3 through 33.9 percent. This share needs to be controlled for because it can be expected on the basis of several theories that it will affect the ethnocentrism of the native population (Elchardus and Siongers 2009).

\section{$\underline{\text { Assessing Ethnocentrism in Dutch Cities }}$}

Before assessing the impact of the cultural and economic climate of Dutch cities on the ethnocentrism of their less-educated inhabitants, table 4 illustrates how indicators for a weak economic position relate to those for cultural capital and cultural insecurity. The table shows the zero-order correlations above the diagonal and the partial correlations controlled for level of education below it. The zero-order correlations confirm that level of education is an ambiguous indicator for both economic position and cultural capital: it is positively related to income and cultural participation alike. This means that the 
negative relationship between level of education and ethnocentrism that has so often been found can in itself not unequivocally be interpreted as confirming either of the two theories outlined above.

\section{[Table 4 about here]}

The correlations below the diagonal reveal that contrary to education, cultural participation is not an ambiguous indicator for one's cultural capital: controlled for education, it neither correlates with income, nor with unemployed. This means that a relationship between cultural participation and ethnocentrism, unlike a relationship between education and ethnocentrism, can unequivocally be interpreted as culturally rather than economically based. The correlations below the diagonal reveal furthermore that, controlled for education, cultural insecurity is not related to income either. To the extent that cultural insecurity can account for the ethnocentrism of less-educated natives, the latter is hence rooted in their limited amount of cultural capital rather than in their weak economic position.

A comparison of the correlations above the diagonal with those below it moreover indicates that although people with high incomes have more embodied cultural capital and are less culturally insecure (above diagonal), this can be fully explained by their higher level of education (below diagonal). In other words: the interest in highbrow culture and the low level of cultural insecurity found among the rich is not rooted in their wealth, but in their higher level of education. This means that the ethnic competition 
theory is only confirmed if we find effects of income and/or being unemployed or not on ethnocentrism that cannot be explained away by these cultural variables.

As the hypotheses need be tested on data with a multilevel structure -765 respondents in 22 metropolitan agglomerations - there is need for multilevel modeling. Table 5 therefore starts with a null model, which shows that five percent of the variance in ethnocentrism exists at city level $(0.05 /(0.05+0.95))$, and consequently ninety-five percent exists at the individual level $(0.95 /(0.05+0.95))$. As shown time and again in previous studies, in model 1 education is negatively related to ethnocentrism: highereducated natives are less ethnocentric than less-educated ones.[7] The question is whether this can be interpreted as a cultural effect, an economic effect, or both. To find this out, the non-ambiguous indicators for one's economic position are entered into model 2 , while the non-ambiguous indicators for one's cultural position are entered into models 3 and 4 .

\section{[table 5 about here]}

Model 2 shows that of the two indicators for one's economic position only income has the that the ethnic competition theory predicts: being unemployed has no effect whatsoever.[8] The income effect is moreover rather weak and hardly reduces the relationship between education and ethnocentrism, even though that is what one would expect if education would operate here as an indicator for a weak economic position. This means that hypothesis 1a needs to be rejected: less-educated natives are not more ethnocentric than higher-educated ones because of their weaker economic position. 
Model 3 shows that cultural participation, an unambiguous indicator for cultural capital, is negatively related to ethnocentrism as could be expected on the basis of the cultural theory: those with ample cultural capital are less ethnocentric than those with little cultural capital.[9] Including cultural participation does reduce the relationship between education and ethnocentrism, to be sure, but does not at all wipe out the latter. This is in accordance with other studies that have also demonstrated that as drivers of cultural tolerance institutionalized (education) and embodied (cultural participation) cultural capital operate largely independently (Achterberg and Houtman 2006; Houtman 2000; Houtman, Achterberg and Derks 2008; Van der Waal 2010a, 2010b; Van der Waal et al. 2010).

Model 4 assesses whether it is indeed cultural insecurity that underlies the ethnocentrism of those with little cultural capital and points out that it actually does. Entering cultural insecurity (which is substantially positively related to ethnocentrism as studies have shown time and again) leads to a considerable decline in the relationship between education and ethnocentrism, while the one between cultural participation and the latter is even completely explained away.[10] Taking into account that, controlled for education, cultural insecurity is not related to unambiguous indicators for one's economic position (table 4), education thus seems to be operating as an indicator for one's cultural capital, and not as an indicator for one's economic position. It is consequently their limited cultural capital and the high level of cultural insecurity that accompanies it, and not their weak economic position, that makes less-educated natives more ethnocentric than higher-educated ones.[11] Hypothesis $1 \mathrm{~b}$ is therefore confirmed: the ethnocentrism 
of less-educated natives can be explained by their small amount of cultural capital and the cultural insecurity that comes with it.[12]

The question remains whether less-educated natives in the most postindustrial cities are least ethnocentric, and if so, whether this has economic and/or cultural roots. This will be answered in four steps. The first one is made in model 5 by entering postindustrialism and assessing whether education has a significant random slope, which proves to be the case.[13] This random slope indicates that the relationship between education and ethnocentrism differs among Dutch cities. The positive and significant effect of postindustrialism furthermore shows that the population in the most postindustrial cities is least ethnocentric.

The second step is taken in model 6 by entering the interaction-effect of postindustrialism with education.[14] This interaction-effect is positive and significant, which is in accordance with what both theories addressed in this article predict: the levels of ethnocentrism of less- and higher-educated natives differ less in the most postindustrial cities. This brings us to the third step: assessing whether this pattern comes about through the mechanism that is assumed by the ethnic competition theory or by the one suggested by Florida's theory (models $7 \mathrm{a}$ and $7 \mathrm{~b}$, respectively).

A comparison of model $7 \mathrm{a}$ with model $7 \mathrm{~b}$ shows that only Florida's theory can account for the circumstance that the gap in ethnocentrism between less- and highereducated natives is narrower in the most postindustrial cities.[15] Economic opportunity structure and its interaction-effect with education clearly do not underlie this pattern (model 7a): they do not yield significant coefficients and consequently do not affect the interaction-effect of postindustrialism with education. Entering the bohemian index and 
its interaction with education, on the contrary, yields significant coefficients that are in the expected direction and account for the narrower gap in ethnocentrism between lessand higher-educated natives in the most post-industrial cities (model 7b). In sum, the narrowness of this gap in the most postindustrial cities cannot be explained by the ample opportunities at the bottom end of the labor market in these cities, but by the more tolerant cultural climate, as measured with Florida's bohemian index. Hypothesis 2a hence needs to be rejected: less-educated natives are not less ethnocentric in the most postindustrial cities due to the better economic opportunity structure there.

Of course, a narrow gap in ethnocentrism between less- and higher-educated natives does in itself say nothing about the actual levels of ethnocentrism in both groups. To test hypothesis $2 \mathrm{~b}$, we need to find out whether less-educated natives in the most postindustrial cities are actually less ethnocentric than in the least postindustrial ones. This requires an additional analysis for less-educated natives (less than 16 years of education, model 1a) and higher-educated natives (at least sixteen years of education, model 1b) separately.[16] Table 6 demonstrates that, controlled for demographic composition and immigrant share, both educational categories are less ethnocentric in cities that score highest on the bohemian index. Put differently, both less- and highereducated natives are least ethnocentric in cities with a more tolerant cultural atmosphere. Figure 1 depicts these results graphically. This confirms hypothesis $2 \mathrm{~b}$ : less-educated natives in the most postindustrial cities are least ethnocentric because of the tolerant cultural atmosphere in these cities.

[table 6 about here] 


\section{[figure 1 about here]}

\section{$\underline{\text { Conclusions and Debate }}$}

Two strands of literature justify the assumption that less-educated natives will be less ethnocentric in postindustrial Dutch cities than in industrial ones. The first theory on this matter combines the ethnic competition theory with the research finding that in the former cities job-competition between immigrants and natives is lowest due to high labor demand at the bottom end of the labor market. Although our analysis confirms that lesseducated natives are indeed less ethnocentric in the most postindustrial cities, this proves however not be driven by these more abundant labor market opportunities. On the one hand, this may seem a remarkable finding, particularly in the light of the strong distributive overtones of our operationalization of ethnocentrism, which was largely based on questions concerning the distribution of scarce resources among 'foreigners' and 'native Dutchmen'. On the other hand, however, this finding is not remarkable at all, because it resonates with reviews of the bulk of ethnocentrism studies by Hainmüller and Hiscox (2007) and Wimmer (2000) that also lead to the conclusion that most empirical evidence is at odds with the ethnic competition theory.

The second explanation that was put to the test assumes that in the most postindustrial cities there is a more tolerant cultural atmosphere than in the least postindustrial ones, which negatively affects the ethnocentrism of the less educated. Our findings support this assumption. At the individual level, the ethnocentrism of lesseducated natives proves to be rooted in their limited amount of cultural capital and the 
cultural insecurity this brings in its wake. At the city level, the lower level of ethnocentrism of less-educated natives in the most postindustrial cities proves to result from the more tolerant cultural atmosphere in those cities.

It is important to point out that previous studies that have ranked cities according to the Bohemian index have merely assumed that the latter is a valid indicator for cultural tolerance. To the best of our knowledge, this is the first study that actually offers confirmatory evidence for this, so as to validate Florida's index: inhabitants of cities that score highest on the index are indeed least ethnocentric. Yet, one can still wonder whether Florida's bohemian index actually measures the tolerance of the urban cultural atmosphere in a valid way, because it may of course capture other features of cities as well. We believe nonetheless that the three most obvious objections, and hence alternative interpretations of its effect on ethnocentrism, are ruled out by the findings we have reported above. In the first place, one may wonder whether the effect of the bohemian index on the ethnocentrism of less-educated urbanites may not simply be a result of the high level of tolerance of the bohemians themselves. We consider this very unlikely, not only because the bohemians constitute a very small part of the urban population ( 0.07 through 2 percent), but also because bohemians tend to be highereducated rather than less-educated.

In the second place, one may wonder whether the bohemian index does not affect the ethnocentrism of less-educated natives as an alternative indicator for (the absence of) job-competition between migrants and the native population after all. The presence of a large share of bohemians may for instance in itself yield substantial labor demand for less-educated urbanites, and may because of that reduce job competition between 
immigrants and less-educated natives at the bottom end of the labor market. This

alternative interpretation of the effect of the bohemian index on the ethnocentrism of lesseducated urbanites is however ruled out by the circumstance that we have already controlled for the economic opportunities at the bottom end of the labor market in our analyses. Moreover, this interpretation cannot account for the finding that the bohemian index reduces the ethnocentrism of the higher-educated, too.

Thirdly, the bohemian index may indicate the job-competition between immigrants and the native population in a more complex way if it somehow captures the degree of ethnic segmentation at the bottom end of the urban labor market, i.e., the degree to which immigrants and natives find employment in different segments of the urban labor market. If such would be the case, the negative effect of the bohemian index on the ethnocentrism of the less-educated could indicate that the latter are less ethnocentric in postindustrial cities, because they face less ethnic competition in postindustrial cities after all, as suggested by the ethnic competition theory. If such would be the case, we would expect to find a similar effect of the economic opportunity structure for less-educated urbanites, which does however prove not to exist, as we have seen (which is all the more problematic, because this constitutes the more direct and hence arguably more valid measurement for ethnic competition). Therefore, we consider this alternative interpretation of the effect of the bohemian index on the ethnocentrism of less-educated urbanites not very plausible either.

Needless to say, although we feel that these three alternative interpretations of the effect of the bohemian index on the ethnocentrism of less-educated urbanites are less plausible than Florida's own interpretation, research into the validity of his index as an 
indicator for the culturally tolerant atmosphere of cities, and on how exactly such a climate affects the ideas of urbanites, is clearly called for.

Another question that calls for further scrutiny is whether and how far our findings travel beyond the Dutch case. Is it likely that similar patterns exist in other western countries? This is of course first of all an open empirical question, but the small geographical size of the Netherlands makes it reasonable to expect that city-level differences in cultural tolerance will be larger rather than smaller in other western countries. It is after all likely that the limited distances between the Dutch metropolitan agglomerations will reduce these differences to levels below these in larger countries, with the United States as the most extreme case in point, of course.

This brings us to a final and more general point. In 1996, Elaine Sharp has stressed that 'the elevation of interests over values as the focus of inquiry in political science leaves the matter of morals-based social conflict on the periphery of the intellectual enterprise' $(1996,741)$. Eleven years later, she made a similar claim, noting that 'if the urban politics field has become marginalized, it is because the field has neglected to develop a contemporary, theoretically grounded version of cultural explanation to go along with its attention to institutions and political economy' (Sharp $2007,55)$. We cordially agree with these observations, but wish to point out that such an emphasis on economic explanations for social and cultural phenomena is hardly limited to the field of urban politics, but applies to political sociology and political science at large, and in fact even to the social sciences generally (cf. Houtman 2003; Kumar 1978, 2004). The customary labeling of the increase in the political salience of cultural issues in western societies as an emergence of 'postindustrial' politics is already a telling case in 
point (e.g., Betz 1994; Clark and Lipset 2001; Clark and Rempel 1997; Inglehart 1990; Kischelt 1997). This widely used label is informed by the equally widely held assumption that it is in fact the socio-economic transition to a postindustrial economy that is responsible for this change in the political climate. Instead of making such far-fetched assumptions about a decisive role of socio-economic variables, we consider it more appropriate to systematically study their empirical validity whenever such is possible. 


\section{Notes}

[1] This finding indicates that, as far as the allocation of natives and immigrants is concerned, Dutch urban labor markets are not fully segmented. If all immigrants would find employment in different labor-market segments than natives would do, there would be no competition over scarce job opportunities between those two groups at all. This is of course not to say that there is no segmentation of Dutch urban labor markets whatsoever - be it between ethnic groups or between any other social groups for that matter -, for such segmentation comes in many forms (cf. Loveridge and Mok 1979). [2] According to Bourdieu (1984) cultural capital fulfils a status function. As such, it serves exclusionary practices and the reproduction of status differences (cf. Houtman 2003, chapter 8). Needless to say, our use of the notion of cultural capital as an ability to understand and appreciate cultural differences differs from Bourdieu's use of the concept, yet is not incompatible with it. Bourdieu simply focuses on other consequences of differences in cultural capital than the ones studied in this article.

[3] The experienced absence of a meaningful social order goes by many other names than cultural insecurity or anomie, such as personal or psychological insecurity. We do however stick to the former labels, as these are most commonly used in studies on the relation of that phenomenon with tolerance towards outgroups (cf. Radkiewicz 2007). [4] http://www.scp.nl/.

[5] http://statline.cbs.nl/statweb/.

[6] All variables in the analyses have been standardized.

[7] Using four degrees of freedom (four variables have been added) leads to a decline in deviance of 60.52 (2069.01- 2008.49). Therefore, model 1 is a significant improvement in 
relation to the null model, for according to the chi square distribution there is need for mere decline of 9.488 in deviance to be significant at the 5 percent level.

[8] It is a significant improvement of model $1((2008.49-2001.71)>5,991)$.

[9] Model 3 is a significant improvement of model 2 (2001.71 - 1990.56 > 3.841).

[10] Model 4 is a significant improvement of model $3((1990.56-1951.44)>3.841)$.

[11] It needs to be emphasized that no incontestable assumptions can be made (nor need to be made) about the causal ordering of cultural capital and cultural tolerance. For in liberal democracies, cultural open-mindedness is just as likely to spark interest in 'highbrow' culture than the other way around, if only because much contemporary art tends to question, deconstruct, and disrupt the legitimacy of the existing social and cultural order (Bell 1976; Jensen 1995). The same goes for the relationship between level of education and cultural tolerance, for open-mindedness is of course a major cultural resource in grasping the complex and abstract issues associated with higher education. The most reasonable assumption is hence that cultural capital and cultural tolerance mutually reinforce each other, as inWeberian 'elective affinity' as compared to causality (Houtman 2003, chapter 8). This does not pose a problem for our analysis in this paper, because its conclusion that the ethnocentrism of less-educated natives does not stem from their weak economic position is independent of this issue of causal ordering. [12] The theory that a limited amount of cultural capital and its concomitant cultural insecurity instead of a weak economic position underlies the ethnocentrism of the lower educated resonates with the social capital explanation that has most notably been formulated by Putnam (2000). At closer scrutiny, the former might even be a valuable 
addition to the latter, because Putnam's explanation seems to lack a clear mechanism that relates social capital to cultural tolerance.

On the one hand, Putnam expects that people who are embedded in diverse social networks and who are politically involved are more tolerant towards outgroups than the socially isolated. How this exactly comes about is however not very clear, partly because he considers tolerance a result of (2000: 356$)$ as much as an indicator for social capital (2000: 362) (cf. Wilson 2001: 225). Yet, the most obvious interpretation seems basically identical to our cultural capital interpretation: those who have contact and deliberate with a wide range of different people get used to people with ideas and values that differ from their own. And the other way around, of course: those who are able to understand and appreciate cultural diversity are more likely to become embedded in culturally diverse social networks and to become politically involved.

On the other hand, in his more recent work Putnam (2007) argues that immigration leads to a decline in social capital, at least in the short run. Again, how this exactly comes about is not clear, but his study shows that increasing ethnic diversity is related to low levels of trust, altruism and community cooperation. This observation seems in line with the explanation used in this article that resistance towards cultural diversity is rooted in cultural insecurity. The cultural disorder that increasing cultural diversity brings in its wake is what according to that explanation sparks cultural insecurity and makes the culturally insecure ethnocentric. This might very well be the underlying mechanism for Putnam's negative relationships between increasing ethnic diversity on the one hand and trust, altruism and community cooperation on the other. [13] Model 5 is a significant improvement of model 4 ((1951.44-1945.19) > 5.991). 
[14] Model 6 is a significant improvement of model $5((1945.19-1942.75)>1.642)$.

[15] Model 7a is not $((1942.75-1940.29)<6.251)$, but model 7b is $((1942.75-1935.44)$ > 6.251) a significant improvement of model 6 .

[16] Model 1a is a significant improvement of the null model ((1127.46-1117.40) > 9.488). Model $1 \mathrm{~b}$ is only a significant improvement of the null model if the bohemian index is entered into the model $((859.99-856.45)>2.706)$ without the control variables, for the latter do all yield insignificant coefficients and the coefficient of the bohemian index is rather weak $((859,99-854,23)<9,488)$. However, to show the reader that the coefficient of the bohemian index is not spurious and attributable to the demographic composition of Dutch cities, we report the model that also includes the control variables. 


\section{References}

Achterberg, P. 2006a. Considering Cultural Conflict. Class Politics and Cultural Politics in Western Societies. Maastricht: Shaker Publishing.

Achterberg, P. 2006b. Class Voting in the New Political Culture - Economic, Cultural and Environmental Voting in 20 Western Countries. International Sociology 21 (2): $237-61$.

Achterberg, P., and D. Houtman. 2006. Why Do So Many People Vote 'Unnaturally'? A Cultural Explanation for Voting Behavior. European Journal of Political Research 45 (1): 75-92.

Achterberg, P., and D. Houtman. 2009. Ideologically 'Illogical'? Why Do the LowerEducated Dutch Display so Little Value Coherence? Social Forces 87 (3): 164970.

Asheim, B., and H. K. Hansen. 2009. Knowledge Bases, Talents, and Contexts: On the Usefulness of the Creative Class Approach in Sweden. Economic Geography 85 (4): $425-42$.

Bauman, Z. 1987. Legislators and Interpreters. On Modernity, Post-Modernity and Intellectuals. Cambridge: Polity Press.

Bell, D. 1976. The Cultural Contradictions of Capitalism. New York: Basic Books.

Betz, H. G. 1994. Radical Right-Wing Populism in Western Europe. New York: St. Martin's Press.

Blalock, H. M.1956. Economic Discrimination and Negro Increase. American Sociological Review 21 (5): 584-88.

Blalock, H. M.1967. Towards a Theory of Minority Group Relations. New York: Wiley. 
Blank, T. (2003). Determinants of National Identity in East and West Germany: An Empirical Comparison of Theories on the Significance of Authoritarianism, Anomie, and General Self-Esteem. Political Psychology 24 (2): 259-88.

Bourdieu, P. 1984. Distinction: A Social Critique on the Judgement of Taste. London: Routledge.

Bourdieu, P. 1986. The Forms of Capital. In Handbook of Theory and Research for the Sociology of Education, edited by J. G. Richardson, 241-58. New York: Greenwood.

Clark, T. N. 1996. Structural Realignment in American City Politics: Less Class, More Race, and a New Political Culture. Urban Affairs Review 31 (2): 367-403.

Clark, T. N., and M. Rempel, eds. 1997. Citizen Politics in Post-Industrial Societies Boulder: WestviewPress.

Clark, T. N., and V. Hoffmann-Martinot, eds.1998. The New Political Culture. Boulder: WestviewPress.

Clark, T. N., and Seymour Martin Lipset, eds. 2001. The Breakdown of Class Politics. A Debate on Post-Industrial Stratification. Washington D.C.: Woodrow Wilson Center Press.

De Groof, S. and M. Elchardus. 2009. Kwetsbaarheid, anomie, autoritarisme en etnocentrisme. In: Vreemden. Naar een cultuursociologische benadering van etnocentrisme, edited by M. Elchardus and J. Siongers, 79-97. Tielt: Uitgeverij Lannoo. 
Deleon, R. E., and K. C. Naff. 2004. Identity Politics and Local Political Culture: Some Comparative Results from the Social Capital Benchmark Survey. Urban Affairs Review 39 (6): 689-719.

Derks, A. 2006. Populism and the Ambivalence of Egalitarianism. How Do the Underprivileged Reconcile a Right Wing Party Preference with Their SocioEconomic Attitudes? World Political Science Review 2 (3): article 1.

DiMaggio, P. 1982. Cultural Capital and School Success: The Impact of Status Culture Participation on the Grades of U.S. High School Students. American Sociological Review 47 (1): 189-201.

DiMaggio, P., and J. Mohr. 1985. Cultural Capital, Educational Attainment, and Marital Selection. American Journal of Sociology 90 (6): 1231-61.

Dumais, S. A. 2002. Cultural Capital, Gender, and School Success: The Role of Habitus. Sociology of Education 75 (1): 44-68.

Drennan, M., S. Larsen, J. Lobo, D. Strumsky, and W. Utomo. 2002. Sectoral Wages, Specialisation and Metropolitan Wages in the United States, 1969-96. Urban Studies 39(7), pp. 1129-42.

Dustmann, C., and I. P. Preston. 2007. Racial and Economic Factors in Attitudes to Immigration. The B.E. Journal of Economic Analysis \& Policy 7: art. 62.

Eitle, T.M., and D. J. Eitle. 2002. Race, Cultural Capital, and the Educational Effects of Participation in Sports. Sociology of Education 75 (1): 123-46.

Elchardus, M., and W. Smits. 2002. Anatomie en oorzaken van het wantrouwen. Brussel. VUBPRESS. 
Elchardus, M., and J. Siongers, eds. 2009. Vreemden. Naar een cultuursociologische benadering van etnocentrisme. Tielt: Uitgeverij Lannoo.

Elliott, J. R. 1999. Putting "Global Cities" In Their Place: Urban Hierarchy and LowIncome Employment during the Post-War Era. Urban Geography 20 (1): 95-115.

Elliott, J. R. 2004. The Work of Cities: Underemployment and Urban Change in Late20th-Century America. Cityscape 7 (1): 107-33.

Emler, N. and E. Frazer. 1999. Politics: The Education Effect. Oxford Review of Education 25 (2): 251-73.

Fainstein, S., I. Gordon, and M. Harloe, eds. 1992. Divided Cities: New York and London in the Contemporary World. Oxford: Blackwell Publishers.

Florida, R. 2002. Bohemia and Economic Geography. Journal of Economic Geography 2 (1): 55-71.

Florida, R. 2003. Cities and the Creative Class. City \& Community 2 (1): 3-19.

Florida, R. 2004. The Rise of the Creative Class: And How It's Transforming Work, Leisure, Community and Everyday Life. Paperback ed. New York: Basic Books.

Florida, R. 2005. Cities and the Creative Class. New York: Routledge.

Fuchs, M. 2003. Rechtsextremismus von Jugendlichen. Zur Erkläringskraft verschiedener theoretischer Konzepte. Kölner Zeitschrift für Soziologie und Sozialpchychologie 55 (4): 654-78.

Fuchs, D., J. Gerhards, and E. Roller. 1993. Wir und die Anderen. Ethnozentrismus in den zwölf Ländern der Europäischen Gemeinschaft. Kölner Zeitschrift für Soziologie und Sozialpsychologie 45 (2): 238-53. 
Gabennesch, H. 1972. Authoritarianism as World View. American Journal of Sociology 77 (5): 857-875.

Ganzeboom, H. 1989. Cultuurdeelname in Nederland. Assen/Maastrict: Van Gorcum.

Hainmüller, J., and M. Hiscox. 2007. Educated Preferences: Explaining Attitudes towards Immigration in Europe. International Organization 61 (2): 399-442.

Houtman D. 2001. Class, Culture and Conservatism, Reassessing Education as a Variable in Political Sociology. In The Breakdown of Class Politics, A Debate on PostIndustrial Stratification, edited by T. N. Clark, and S. M. Lipset, 161-95. Washington D.C.: Woodrow Wilson Center Press.

Houtman, D. 2003. Class and Politics in Contemporary Social Science. "Marxism Lite" and Its Blind Spot for Culture. New York: Aldine de Gruyter.

Houtman, D., P. Achterberg, and A. Derks. 2008. Farewell to the Leftist Working Class. New Brunswick: Transaction Publishers.

Hoyman, M., and C. Faricy. 2009. It Takes a Village: A Test of the Creative Class, Social Capital, and Human Capital Theories. Urban Affairs Review 44 (3): 311-33.

Inglehart, R. 1990. Culture Shift in Advanced Industrial Society. Princeton: Princeton University Press.

Jensen, R. 1995. The Culture Wars, 1965-1995: A Historian's Map. Journal of Social History 2 (October): 17-37.

Kasarda, J. D. 1985. Urban Change and Minority Opportunities. In: The New Urban Reality, edited by P.E. Peterson, 33-67. Washington D.C.: Brookings. 
Kasarda, J. D. and J. Friedrichs. 1985. Comparative Demographic-Employment Mismatches in U.S. and West German Cities. Research in the Sociology of Work 3 (1): $1-30$.

Kasarda, J. D., and J. Friedrichs. 1986. Economic Transformation, Minorities, and Urban Demographic-Employment Mismatch in the U.S. and West Germany. In The Future of the Metropolis. Berlin, London, Paris, New York Economic Aspects, edited by H.J. Ewers, J.B. Goddard, and H. Matzerath, 221-49. Berlin / New York: Walter de Gruyter.

Katsillis, J., and R. Rubinson. 1990. Cultural Capital, Student Achievement, and Educational Reproduction: The Case of Greece. American Sociological Review 55 (2): 270-79.King, A.D. 1990. Global Cities: Post-Imperialism and the Internationalization of London. London / New York: Routledge.

Kluegel, J. R. and E. R. Smith. 1983. Affirmative Action Attitudes: Effects of SelfInterest, Racial Affect, and Stratification Beliefs on Whites' Views. Social Forces 61 (3): 797-824.

Kitschelt, H. 1997. The Radical Right in Western Europe. Ann Arbor: The University of Michigan Press.

Kuklinski, J.H., M.D. Cobb, and M. Gilens.1997. Racial Attitudes and the "New South". The Journal of Politics 59 (2): 323-49.

Kumar, K. 1978. Prophecy and Progress: The Sociology of Industrial and Post-Industrial Society. London: The Penguin Press.

Kumar, K. 2004. From Post-Industrial to Post-Modern Society: New Theories of the Contemporary World. Oxford: Wiley-Blackwell. 
Loveridge, R., and A. L. Mok. 1979. Theories of Labour Market Segmentation: A Critique. London: Martinus Nijhoff.

Lutterman, K.G., and R. Middleton. 1970. Authoritarianism, Anomia, and Prejudice. Social Forces 48 (3): 485-92.

Manevska, K., J van der Waal, P. Achterberg, D. Houtman, and W. de Koster. 2010. 'Sommigen zijn gelijker dan anderen.' Economisch egalitarisme en verzorgingsstaatchauvinisme in Nederland. Sociologie 6 (1): 3-25.

Markusen, A., and G. Schrock. 2006. The Artistic Dividend: Urban Artistic Specialisation and Economic Development Implications. Urban Studies 43 (10): 1661-86.

McDill, E.L. 1961. Anomie, Authoritarianism, Prejudice, and Socio-Economic status: An Attempt at Clarification. Social Forces 39 (3): 239-45.

Mulford, C. 1968. Ethnocentrism and Attitudes toward the Mentally Ill. The Sociological Quarterly 9 (1): 107-11.

Oliver, J., and T. Mendelberg 2000. Reconsidering the Environmental Determinants of White Racial Attitudes. American Journal of Political Science 44 (3); 574-89.

Olzak, S. 1992. The Dynamics of Ethnic Competition and Conflict. Stanford: Stanford University Press.

O'Rourke, K.H., and R. Sinnott. 2006. The Determinants of Individual Attitudes Towards Immigration. European Journal of Political Economy 22 (4): 838-61.

Putnam, R.D. 2000. Bowling Alone: The Collapse and Revival of American Community. New York. Simon Schuster. 
Putnam, R.D. 2007. E Pluribus Unum: Diversity and Community in the Twenty-first Century. Scandinavian Political Studies 30 (2): 137-74.

Radkiewicz, P. 2007. Several Reasons Why Social Anomie and Political Alienation May Influence Ethnocentric Attitudes. The Compensating Role of AuthoritarianParanoid Beliefs. Polish Psychological Bulletin 38 (1): 5-14.

Roberts, A.H., and M. Rokeach. 1956. Anomie, Authoritarianism, and Prejudice: A Replication. American Journal of Sociology 61 (3): 355-58.

Roscigno, V. J., L. M. Garcia. and D. Bobbitt-Zeher. 2007. Social Closure and Processes of Race/Sex Employment Discrimination. The ANNALS of the American Academy of Political and Social Science 609 (16): 16-48.

Rosdil, D. L. 1991. The Context of Radical Populism in U.S. Cities: A Comparative Analysis. Journal of Urban Affairs 13 (1): 77-96.

Sassen, S. 2000. Cities in a World Economy. 2 ed. London: Pine Forge Press.

Sassen, S. 2001. The Global City: New York, London, Tokyo. 2 ed. Princeton: Princeton University Press.

Sassen, S. 2006. Cities in a World Economy. 3 ed. Thousand Oaks: Pine Forge Press.

Sassen-Koob, S. 1985. Capital Mobility and Labor Migration: Their Expression in Core Cities. In Urbanization in the World-Economy, edited by M. Timberlake, 231-65. Orlando: Academic Press.

Sharp, E. B. 1996. Culture Wars and Local Politics. Local Government's Role in Social Conflict. Urban Affairs Review 31 (6): 738-58.

Sharp, E. B. (ed.). 1999. Culture Wars and Local Politics. Kansas: University Press of Kansas. 
Sharp, E. B. 2002. Culture, Institutions, and Urban Officials' Responses to Morality Issues. Political Research Quarterly 55 (4): 861-83.

Sharp, E. B. 2007. Revitalizing Urban Research: Can Cultural Explanation Bring Us Back from the Periphery. Urban Affairs Review 43 (1): 55-75.

Sharp E. B., and M. R. Joslyn. 2008. Culture, Segregation, and Tolerance in Urban America. Social Science Quarterly 89 (3): 573-91.

Sniderman, P. M., and L. Hagendoorn. 2007. When Ways of Life Collide. Multiculturalism and Its Discontent in the Netherlands. Princeton: Princeton University Press.

Sniderman, P. M., L. Hagendoorn, and M. Prior. 2004. Predispositional Factors and Situational Triggers: Exclusionary reactions to Immigrant Minorities. American Political Science Review 98 (1): 35-50.

Srole, L. 1956. Social Integration and Certain Corollaries: An Exploratory Study. American Sociological Review 21 (6): 709-16.

Van der Waal, J. 2009. De invloed van immigratie op de lonen in Amsterdam en Rotterdam. De substitutiethese getoetst in twee stedelijke contexten. Sociologie 5(1), pp. 89-111.

Van der Waal, J. 2010a. Stedelijke economieën in een tijd van mondialisering. Arbeidsmarktkansen en etnocentrisme van laagopgeleiden in Nederlandse steden. Amsterdam: Amsterdam University Press.

Van der Waal, J. 2010b. Unravelling the Global City Debate. Economic Inequality and Ethnocentrism in Contemporary Dutch Cities. Doctoral dissertation, Erasmus University Rotterdam. 
Van der Waal, J. 2011. Post-Industrialization, Immigration, and Unemployment. How and Why the Impact of Immigration on Unemployment Differs Between Dutch Cities. Forthcoming in Urban Studies.

Van der Waal, J., and P. Achterberg. 2006. Stille revolutie, contra-revolutie of cultureel conflict? Veranderingen in de politieke cultuur en hun invloed op het klassengebonden stemgedrag. Res Publica 46 (4): 369-92.

Van der Waal, J., P. Achterberg, D. Houtman, W. de Koster, and K. Manevska. 2010. "Some are More Equal than Others." Economic Egalitarianism and Welfare Chauvinism in the Netherlands. Journal of European Social Policy 20 (4): 35063.

Van der Waal, J., and J. Burgers. 2009a. Ethnic Competition in Contemporary Cities. The Effects of Job Opportunities and Residential Segregation. In City in Sight. Dutch Dealings with Urban Problems, edited by J. W. Duyvendak, F. Hendriks, and M. Van Niekerk, 25-40. Amsterdam: Amsterdam University Press.

Van der Waal, J., and J. Burgers. 2009b. Unravelling the Global City Debate on Social Inequality: A Firm-level Analysis of Wage Inequality in Amsterdam and Rotterdam. Urban Studies 46 (13): 2715-29.

Van der Waal, J., and J. Burgers. 2011. Post-Industrialisation, Job Opportunities and Ethnocentrism. A Comparison of Twenty-two Dutch Urban Economies. Urban Studies 48 (4).

Wacquant, L. 2008. Urban Outcasts: A Comparative Sociology of Advanced Marginality. Cambridge: Polity Press. 
Weakliem, D.L., and R. Biggert. 1999. Region and Political Opinion in the Contemporary United States. Social Forces 77 (3): 863-86.

Weber, M. [1922] 2006. Wirtschaft und Gesellschaft. Paderborn: Voltmedia.

Weil, F.D. 1985. The Variable Effects of Education on Liberal Attitudes: A ComparativeHistorical Analysis of Anti-Semitism Using Public Opinion Survey Data. American Sociological Review 50 (4): 458-74.

Wilson, J. 2001. Dr. Putnam's Social Lubricant. Contemporary Sociology 30 (3): 225227.

Wimmer, A. 2000. Racism in Nationalised States: A Framework for Comparative Research. In Comparative Perspectives on Racism, edited by J ter Wal, and M. Verkuyten, 47-72. Aldershot: Ashgate.

Zipp, J.F. 1986. Social Class and Social Liberalism. Sociological Forum 1 (2): 301-29. 
Appendix

[figure 2 about here] 


\section{Tables, figures and captions figures}

Table 1: measurement ethnocentrism.

\section{Items}

Factor

loadings

Suppose there are two employees that differ in one respect, but are

0.74

equal in all others. If only one of them can be considered for

promotion, who should it be? [a foreigner / should not matter / a

Dutchman]

Suppose there are two employees that differ in one respect, but are

0.52

equal in all others. If one of them needs to be dismissed because of economic reasons, who should it be? [a Dutchman / should not

matter / a foreigner]

We would like to know who you consider most entitled to a house

0.79

in time of shortage of housing. [foreign family / should not matter

/ a Dutch family]

What do you think in general of the number of people with another

0.65

nationality living in our country? [too many / many, but not too

many / not too many]

$\mathrm{R}^{2}$

46.41

Cronbach's $\alpha$

$N$

765

Source: Cultural Change in the Netherlands Surveys 2004 and 2006 
Table 2: measurement cultural participation

How many times did you visit a classical music concert in the past $\quad 0.80$

12 months? [not / once / 2-3 times / 4-11 times / once a month]

How many times did you visit a museum in the past 12 months? $\quad 0.69$

[not / once / 2-3 times / 4-11 times / once a month]

How many times did you visit an opera in the past 12 months? $\quad 0.74$

[not / once / 2-3 times / 4-11 times / once a month]

How many times did you visit a play or show in the past $12 \quad 0.78$

months? [not / once / 2-3 times / 4-11 times / once a month]

$\begin{array}{ll}\mathrm{R}^{2} & 57.11\end{array}$

$\begin{array}{ll}\text { Cronbach's } \alpha & 0.74\end{array}$

$\begin{array}{ll}\mathrm{N} & 765\end{array}$

Source: Cultural Change in the Netherlands Surveys 2004 and 2006 
Table 3: measurement cultural insecurity

Items

Factor loadings

Generally speaking, would you say that most people can be trusted

0.59

or that you can't be too careful in life? [most people can be trusted

/ you can't be too careful]

There are so many different ideas about what is right and what is

0.85

wrong, that sometimes one doesn't know what to expect [strongly

disagree / disagree / neither agree nor disagree / agree / strongly

agree]

Everything changes so rapidly today that one often hardly knows

what is good and what is bad [strongly disagree / disagree / neither

agree nor disagree / agree / strongly agree]

People like me don't have any say about what the government does

[disagree / agree]

$\mathrm{R}^{2}$

52.01

Cronbach's $\alpha$

0.67

$\mathrm{N}$

765

Source: Cultural Change in the Netherlands Surveys 2004 and 2006 
Table 4: zero-order correlations (above diagonal) and partial correlations controlled for education (below diagonal) between indicators for economic position (income en unemployed), cultural position (cultural participation and cultural insecurity) and education.
(1)
(2)
(3)
(4)
(5)

\begin{tabular}{llllll}
\hline (1) Cultural & 1.00 & $-0.29 * * *$ & $-0.11 * *$ & $-0.37 * * *$ & 0.01 \\
insecurity & & & &
\end{tabular}

(2) Cultural

participation

$\begin{array}{lllll}-0.22 * * * & 1.00 & 0.08 * & 0.29 * * * & -0.04\end{array}$

(3) Income

$-0.07$

0.05

1.00

$0.11 * * \quad-0.06$

(4) Education

$-$

$-$

-

1.00

0.01

(5) Unemployed

0.01

$-0.04$

$-0.05$

1.00

$\mathrm{N}=765$

Source: Cultural Change in the Netherlands Surveys 2004 and 2006, Atlas of

Municipalities 2004, and Statline, Statistics Netherlands (CBS) (own calculations).

$* * * \mathrm{p}<0.001 ; * * \mathrm{p}<0.01 ; * \mathrm{p}<0.05$ 
Table 5: ethnocentrism of the native population in the 22 Dutch metropolitan agglomerations. (Multilevel regression analysis; entries are regression coefficients; estimation: maximum likelihood)

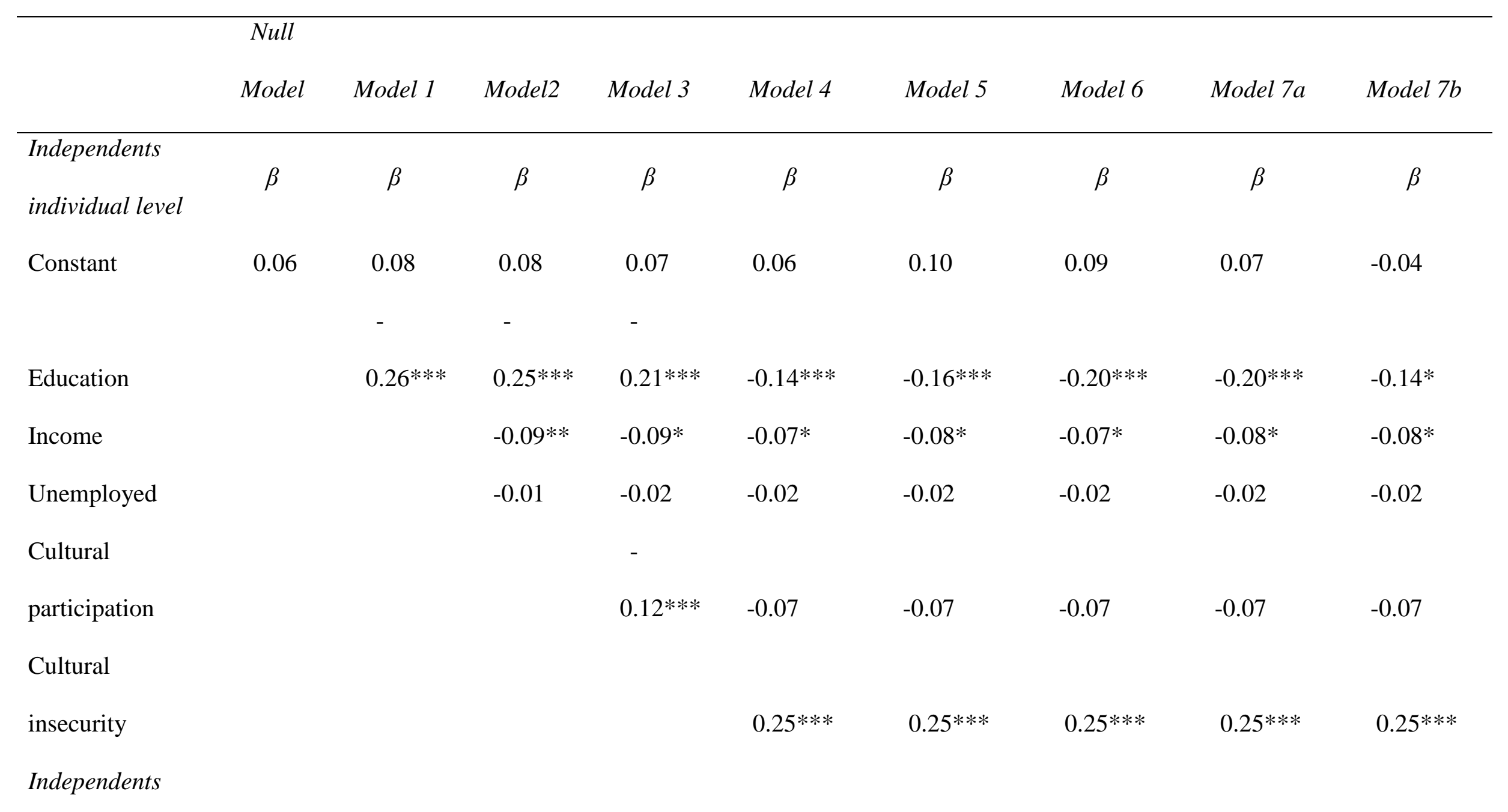


city level

Postindustrialism

$-0.09 \sim$

$-0.09$

$-0.09$

0.05

Economic

opportunity

structure

0.08

Bohemian index

Cross-level

interactions

\section{Postindustrialism}

* education

0.08

$0.08 \sim$

0.00

\section{Economic}

opportunity

structure *

education

Bohemian index

* education

Controls 


\begin{tabular}{|c|c|c|c|c|c|c|c|c|c|}
\hline Gender & & 0.04 & 0.03 & 0.03 & 0.01 & 0.01 & 0.01 & 0.01 & 0.01 \\
\hline Age & & -0.02 & -0.02 & 0.00 & -0.02 & -0.01 & -0.01 & -0.01 & -0.01 \\
\hline Year & & -0.02 & -0.02 & -0.01 & -0.00 & -0.01 & -0.01 & -0.02 & -0.02 \\
\hline Immigrant share & & & & & & & & -0.06 & -0.04 \\
\hline \multicolumn{10}{|l|}{ Variance city } \\
\hline \multicolumn{10}{|l|}{ level } \\
\hline$(\mathrm{N}=22)$ & 0.05 & 0.04 & 0.04 & 0.04 & 0.03 & 0.03 & 0.03 & 0.02 & 0.01 \\
\hline \multicolumn{10}{|l|}{ Variance } \\
\hline \multicolumn{10}{|l|}{ individual level } \\
\hline$(\mathrm{N}=765)$ & 0.95 & 0.87 & 0.86 & 0.85 & 0.81 & 0.80 & 0.80 & 0.80 & 0.80 \\
\hline \multicolumn{10}{|l|}{ Random slope } \\
\hline education*10 & & & & & & 0.10 & 0.04 & 0.04 & 0.01 \\
\hline Deviance & 2069.01 & 2008.49 & 2001.71 & 1990.56 & 1951.44 & 1945.19 & 1942.75 & 1940.29 & 1935.44 \\
\hline DF & & 3 & 2 & 1 & 1 & 2 & 1 & 2 & 2 \\
\hline
\end{tabular}

Source: Cultural Change in the Netherlands Surveys 2004 and 2006, Atlas of Municipalities 2004, and Statline, Statistics Netherlands (CBS) (own calculations).

$* * *=\mathrm{p}<0.01 ; * * \mathrm{p}<0.05 ; * \mathrm{p}<0.1$ two-sided. $\sim \mathrm{p}<0.1$ one-sided. 
Table 6: ethnocentrism of the native population in the 22 Dutch metropolitan agglomerations. (Multilevel regression analysis; entries are regression coefficients; estimation: maximum likelihood)

\begin{tabular}{|c|c|c|c|c|}
\hline & \multicolumn{2}{|c|}{ Less educated } & \multicolumn{2}{|c|}{ Higher educated } \\
\hline & Null Model & Model la & Null model & Model $1 b$ \\
\hline Independents & $\beta$ & $\beta$ & $\beta$ & $\beta$ \\
\hline Constant & $0.31 * * *$ & $0.21 * *$ & $-0.27 * * *$ & $-0.27 * * *$ \\
\hline Bohemian index & & $-0.25 * *$ & & $-0.12 \sim$ \\
\hline \multicolumn{5}{|l|}{ Controls } \\
\hline Gender & & 0.03 & & 0.05 \\
\hline Age & & -0.05 & & 0.04 \\
\hline Year & & -0.02 & & -0.06 \\
\hline Immigrant share & & -0.04 & & -0.00 \\
\hline \multicolumn{5}{|c|}{ Variance city level } \\
\hline$(\mathrm{N}=22)$ & $0.07 *$ & 0.01 & $0.03 \sim$ & 0.01 \\
\hline \multicolumn{5}{|c|}{ Variance individual } \\
\hline level & $1.14 * * *$ & $1.14 * * *$ & $0.60 * * *$ & $0.60 * * *$ \\
\hline Deviance & 1127.46 & 1117.40 & 859.99 & 854.23 \\
\hline $\mathrm{DF}$ & & 4 & & 4 \\
\hline $\mathrm{N}$ & 384 & 384 & 381 & 381 \\
\hline
\end{tabular}

Source: Cultural Change in the Netherlands Surveys 2004 and 2006, Atlas of

Municipalities 2004, and Statline, Statistics Netherlands (CBS) (own calculations).

$* * *=\mathrm{p}<0.01 ; * * \mathrm{p}<0.05 ; * \mathrm{p}<0.1$ two-sided. $\sim \mathrm{p}<0.1$ one-sided. 


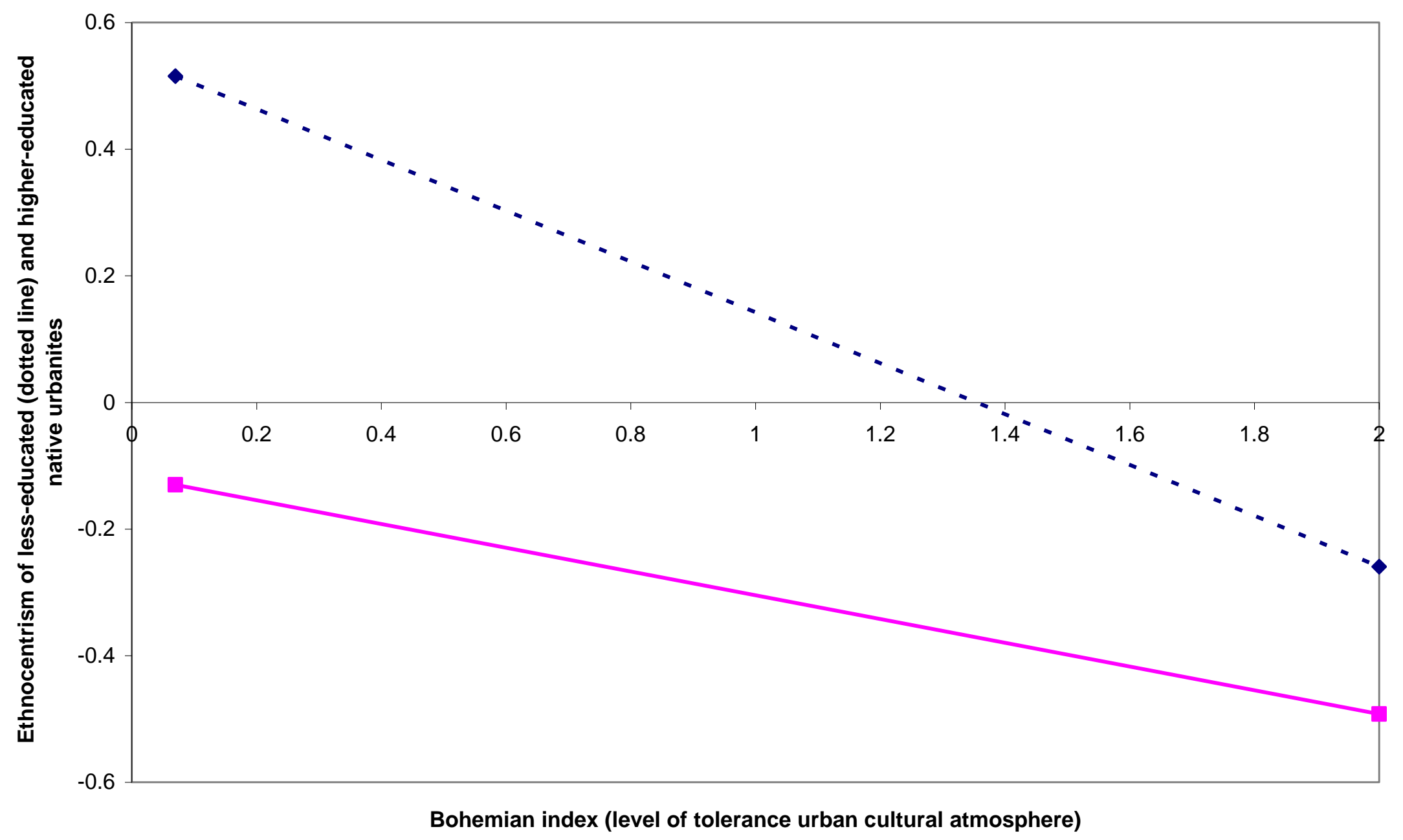




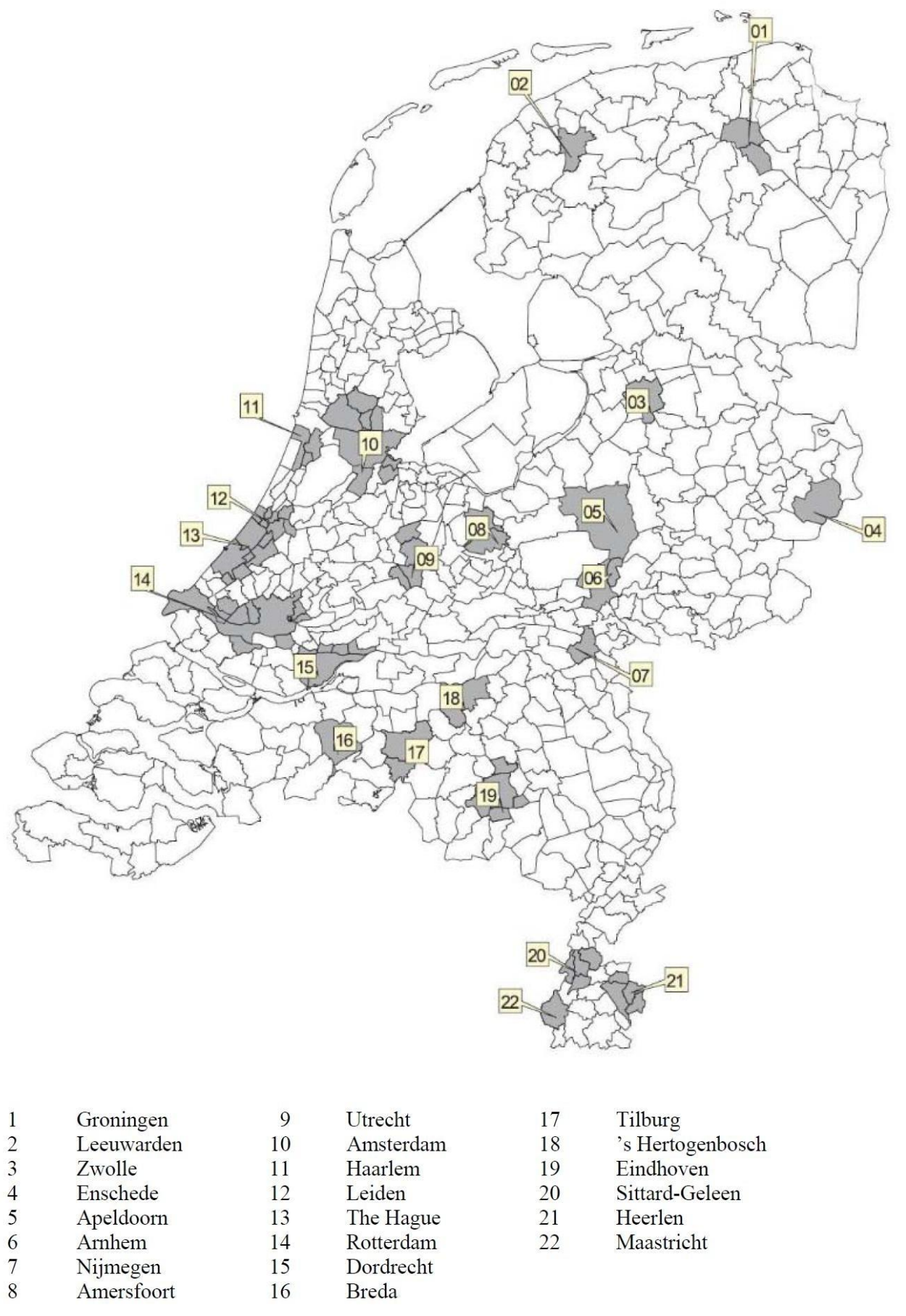




\section{Caption figure 1}

Figure 1: the ethnocentrism of less-educated natives (dotted line) and higher-educated natives in the 22 Dutch metropolitan agglomerations by the level of tolerance of the urban cultural atmosphere

\section{Caption figure 2}

Figure 2: the 22 Dutch metropolitan agglomerations 